\title{
A new species of Tonnoidea Suter, 1813 (Gastropoda Bursi- dae) for the Italian Pliocene: Bursa transeuntis n. sp.
}

\author{
Maurizio Forli' \& Carlo Smriglio,** \\ ${ }^{1}$ via Grocco 16, 59100 Prato (PO), Italia; e-mail: forli.maurizio@gmail.com \\ ${ }^{2}$ Dipartimento di Scienze, Università “Roma Tre”, Viale Marconi 446, 00146 Roma, Italy; e-mail: csmriglio@alice.it \\ ${ }^{*}$ Corresponding author
}

\begin{abstract}
The recent revision for the species of the complex of Bursa scrobilator (Linnaeus, 1758) for the Atlanto-Mediterranean area recognized the existence of three morphologically distinct taxa: two Recent, Bursa scrobilator scrobilator (Linnaeus, 1758) and Bursa scrobilator coriacea (Reeve, 1844) currently considered subspecies, and the fossil and extinct Bursa nodosa (Borson, 1825). Recently, the phylogenetic relationships of bursid gastropods has been reconstructed and the generic name Talisman de Folin, 1887, based on a larval shell of "Bursa" scrobilator scrobilator, has been resurrected. Consequently, the two subspecies are now named as Talisman scrobilator scrobilator and Talisman scrobilator coriacea. During the check of the Italian fossil specimens of the $T$. scrobilator complex, in addition to the specimens of the well-known $B$. nodosa, has been separated a second fossil and extinct species that despite careful research, could not be identified with the fossil species currently known for Italian paleontological deposits: this is here described with the name of Bursa transeuntis n. sp. The morphological relationships of B. transeuntis n. sp., B. nodosa and related taxa are also discussed.
\end{abstract}

KEY WORDS Taxonomy; Tonnoidea; Bursidae; fossil; new species; distribution.

Received 16.03.2021; accepted 08.05.2021; published online 30.06.2021

\section{INTRODUCTION}

A recent review of the species distributed in the Atlanto-Mediterranean area attributable to the Bursa scrobilator (Linnaeus, 1758) complex (Smriglio et al., 2019) allowed to discriminate two recent subspecies and to recognize Bursa nodosa (Borson, 1825) as the probable ancestor of both. The recently published work by Sanders et al. (2020) reconstructing the phylogenetic relationships of the species attributed to Bursidae Thiele, 1925, showed that these belong to a monophyletic group as opposed to Bursa Thiele, 1925 which has been shown to be polyphyletic, therefore the generic name Talisman de Folin, 1887 is restored and is also used for both subspecies Talisman scrobilator scrobilator (Linnaeus, 1758) and Talisman scrobilator coriacea (Reeve, 1844).

During the examination of fossil specimens relating to Talisman scrobilator complex, some specimens of a not identifiable species of fossil Bursidae, coming from the locality of Ciuciano (San Gimignano, Tuscany), have been separated. Bursa transeuntis $\mathrm{n}$. sp. is then described comparing it with other similar fossil species of Tonnoidea Suter, 1913 known for Miocene-Pliocene geological period, clarifying further the systematic frameworks. 


\section{MATERIAL AND METHODS}

\section{Geological setting}

The type locality, in the municipality of San Gimignano (Siena), is known in fossil malacological literature as "Ciuciano", from a local group of houses, part of the Valdelsa Basin (Benvenuti et al., 2014; Dominici et al., 2018). The most widespread Pliocene marine sediments in these surroundings are slightly clayey, very fossiliferous yellow sands, and Ciuciano is the type local- ity of some Pliocene molluscs (Forli \& Dell'Angelo, 2000; Brunetti \& Della Bella, 2010). Researchers refer these sands to the Zanclean on the base of the associated molluscan fauna, with no independent evidence (Chirli, 1997; Dell'Angelo \& Forli, 2000; Brunetti \& Della Bella, 2010; Brunetti \& Forli, 2010), an opinion not substantiated by available biostratigraphic studies such as Capezzuoli et al. (2005), who refer to the Ciuciano succession as "Castel San Gimignano" (see their figures 2, 6 and 10: here modified in Fig. 1). The latter is about $60 \mathrm{~m}$-thick and formed from a

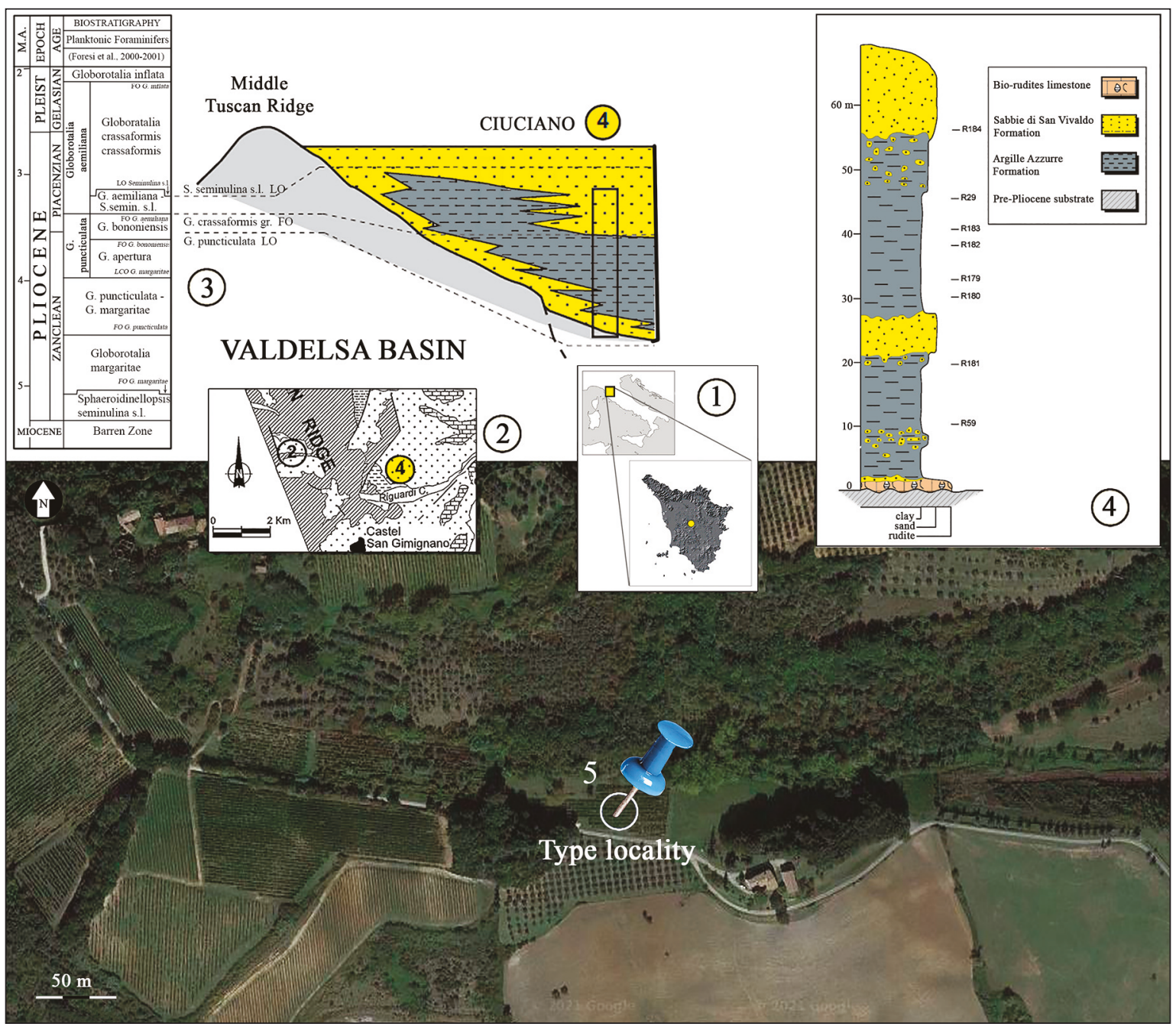

Figure 1. Schematic geological drawings of the outcrop Ciuciano, in the southern part of the Valdelsa basin (by Capezzuoli et al., 2005, modified). 1) Study Area in the central Tuscany; 2) Geological sketch of the southern part of the Valdelsa basin with the position of Ciuciano (Castel San Gimignano in the original text); 3) Schematic stratigraphic relations of the Pliocene Ciuciano deposits and their bio-chronostratigraphic setting on a longitudinal section along the southern part of the Valdelsa Basin (not in scale); 4) Stratigraphic log of the Pliocene succession in the Ciuciano area; 5) Position of the Type Locality. [Image satellite from Google Maps (April 2021)]. 
basal biorudite limestone, rapidly followed upward by a $40 \mathrm{~m}$-thick clayey unit attributed to biozone MPL4b (Capezzuoli et al., 2005, Benvenuti et al., 2014; Dominici et al., 2018). Clays are overlain by the fossiliferous Ciuciano sands (called "Sabbie di San Vivaldo"), which are topped by the Buonriposo-Pescille calcarenite, also attributed to zone MPL4b by Nalin et al. (2016). These constrains allow to refer the Ciuciano sands to the lower Piacenzian, extending the range of some molluscan species present in the type locality [e. g. Bolma fimbriata (Borson, 1821), Stellaria testigera (Bronn, 1831)] (Fig. 1).

\section{Methods}

All the specimens of new species are from a Pliocene outcrop located in Ciuciano, Tuscany (Italy).

Current systematics here adopted is based on World Register of Marine Species (WoRMS, http://www.marinespecies.org/; last accessed March 2021).

ACRONYMS AND ABBREVIATION. BS, Bellardi \& Sacco collection, Regional Museum of Natural Sciences of Turin (Turin, Italy); CS-PM, Carlo Smriglio \& Paolo Mariottini collection (Rome, Italy); MCZR-FS, Francesco Settepassi collection, Museum of Zoology of Rome (section collections of Malacology), Italy; MCZR-M, Monterosato collection, Museum of Zoology of Rome, Italy; MFC, Maurizio Forli collection (Prato, Italy); MNHN, Muséum national d'Histoire naturelle, Paris, France; MRSNT, Regional Museum of Natural Sciences, Turin, Italy; $\mathrm{H}=$ height; $\mathrm{W}=$ width; $\mathrm{Sh}=$ shell/shells. Measurements in millimeters.

\section{RESULTS}

\section{Systematics}

Classis GASTROPODA Cuvier, 1795

Subclassis CAENOGASTROPODA Cox, 1960

Ordo LITTORINIMORPHA Golikov et Starobogatov, 1975

Superfamilia TONNOIDEA Suter, 1913

Familia BURSIDAE Thiele, 1925

Genus Bursa Röding, 1798
Type species. Bursa monitata Röding, 1798 accepted as Bursa bufonia (Gmelin, 1791) (by subsequent designation). Recent.

Bursa transeuntis n. sp. (Figs. 2-6)

http://zoobank.org/urn:lsid:zoobank.org:act:E7E1A 5DB-E779-4EA7-9593-FCB8CE13F34F

Bursa (Bufonariella) scrobilator - Inzani, 1986: 56, pl. 1, fig. 1

Bursa nodosa - Bozzetti, 1991: 3, fig. 2 (pars)

Bursa (Bufonariella) nodosa - Baluk, 1995: 210, p. 18, fig. 4

Bursa scrobilator - Chirli, 2008: 103, pl. 38, figs. $1-2$

Bursa scrobilator - Kovacs \& Vician, 2018: 93, figs. 48-49

TYPE MATERIAL. Holotype MRSNT-P/251 (Fig. 2); Paratype 1 temporarly retained in MFC (Fig. 3); Paratype 2 temporarly retained in MFC (Fig. 4); Paratype 3 (juvenile specimen) CS-PM (Fig. 5); Paratype 4 CS-PM (Fig. 6); all from type locality.

Type Locality. Ciuciano, San Gimignano (Siena), Tuscany, Italy. Lat $43^{\circ} 25^{\prime} 29.4$ 'N, Long. $11^{\circ} 02^{\prime} 06.8^{\prime \prime} \mathrm{E}$ (Google Maps, 2021) and close surroundings.

DESCRIPTION OF THE HOLOTYPE. Spiral gastropod shell rather elongated $(\mathrm{H}=47 \mathrm{xW}=24)$, thick and solid, of medium size for the genus, from 34 to 49 $\mathrm{mm}$ in size. Protoconch planktotrophic. Teleoconch of 5.5/6.5 spiral whorls, weakly but entirely carved by dense and not very prominent dotted spiral cords; 3 important spiral cords are highlighted, bearing large rounded nodules on the top and covered by dotted cords which give it a "dashed" look. The two adapical cords of greater size. Evident varices with protuberant and superficially striated knobs, sculpted with the same hatching which in some areas becomes slightly grainy. Teleoconch sculpted from weak irregular spiral cords, dashed and of various sizes, which in some areas form read rows of pustules and/or spaced granules, which form a rather rough and wrinkled surface. Axial sculpture consists of growth lines. Wide, oval and elongated aperture, height about half of the shell length. Thick and concave columellar callus with 14 irregular folds. Rounded peristome, thick and callused, plicate with parallel small cords. Outer lip 
surrounded by 3 evident tubercles. Deep and incised anal canal, short and open siphonal canal.

VARIABILITY. Paratype 1: $\mathrm{H}=49, \mathrm{~W}=25$; paratype 2: $\mathrm{H}=34, \mathrm{~W}=18.2$; paratype 3 (juvenile specimen): $\mathrm{H}=21, \mathrm{~W}=12.8$, paratype $4: \mathrm{H}=47.5$, $\mathrm{W}=24$

STRATIGRAPHIC AND GEOGRAPHIC DISTRIBUTION. Currently known from the type locality, Piacenzian of Italy (this work) and the Miocene, Badenian, from Korytnica, Poland (Baluk, 1995) and Letkés, Hungary (Kovács \& Vicián, 2017).

ETyMOLOGy. From Latin "transeuntis" = transition, referring to the stratigraphic position of the original Pliocene deposit, between the Miocene specimens and the Recent.

\section{Bursa nodosa (Borson, 1825) (Figs. 8-12)}

Murex nodosus Borson, 1825: 310

Ranella nodosa - Bellardi, 1873: 233, pl. 15, fig. 5 Ranella nodosa var. subanodosa - Sacco, 1890: No. 2479

Ranella nodosa var. mioquinqueseriata - Sacco, 1890: No. 2480

Bursa (Bufonariella) nodosa - Pavia, 1976: 153, pl. 2, figs. 2, 5

Bursa scrobilator - Chirli, 2008: 103, pl. 38, figs. 3-4

Material eXAmined. Murex nodosus, lectotype (BS.010.03.001/01) and 2 paralectotypes, (BS.010. 03.001/02). Italy, Valleandona, "Astian”, Piacenzian, Pliocene, Stefano Borson collection, MRSNT.

Ranella nodosa var. subanodosa Sacco, 1890, one syntype, BS.010.03.002, BS; Ranella nodosa var. mioquinqueseriata Sacco, 1890, two syntypes, BS.010.03.003, BS, MRSNT.

Bursa nodosa, 2 sh, Italy, Sicily, Monte Pellegrino, (MCZR-M, ex Brugnone coll.); 6 sh, Italy, Sicily, Altavilla, (MCZR-M, ex Brugnone coll.); 3 sh, no data, MCZR-FS; 2 sh, Italy, "Astian", MCZR-FS; 1 sh, Italy, Pliocene "upper", MCZRFS; 1 sh, Italy, Sicily, Altavilla, Pliocene, MCZRFS, (legit A.G. Segre); 1 sh, Italy, Tuscany, Val d'Elsa, Siena, Early Pliocene, MZB16604; 1 sh, Italy, Piedmont, Val Vergnana, Turin, Miocene, Upper Burdigalian, MZB43376; 18 sh, Italy, Tuscany, Podere San'Uliviere, San Gimignano,
Pliocene, MFC; 1 sh, Italy, Emilia-Romagna, Castellarquato, Pliocene, MFC.

Description. A brief description of this species is reported: spiral gastropod shell, thick and very solid, of medium size for the genus, from 35 to 55 $\mathrm{mm}$ in size. Protoconch planktotrophic. Teleoconch of 4/6 spiral whorls, weakly sculptured or smooth, if sculptured with 3 spiral cords, bearing strongly rounded nodules on the top. The two adapical cords of greater size. Evident varices with protuberant knobs, superficially striated and/or weakly granulose. Teleoconch sculptured by irregular spiral cords of various size and thickness, evident rows of pustules and granules with well-defined interspaces are present, forming a rough, strongly tessellated and wrinkled surface. Aperture wide, oval and elongated, height about half of the shell length. Adult specimens with thick and roundish columellar callus with 1420 irregular folds. Rounded peristome, thick and callused, plicate with parallel small cords. Outer lip with 3 evident and stout tubercles. Anal canal deep and well incised, siphonal canal short and open.

STRATIGRAPHIC AND GEOGRAPHIC DISTRIBUTION. Bursa nodosa is an extinct species well known for the Italian and European fossil deposits from Miocene to Pliocene (Bellardi, 1873; D'Ancona, 1872; Coppi, 1880; Malagoli, 1884; Greco \& Lima, 1974; Caprotti, 1976; Cossmann, 1903; Pavia, 1976; Baluk, 1995; Vera-Peláez et al., 1996; Landau et al., 2004; Brunetti \& Vecchi, 2005; Chirli, 2008 (as B. scrobilator); Smriglio et al., 2019).

Aquitanobursa tuberosa (Grateloup 1833) (Fig. 15) (type by subsequent designation), comb. nov.= Apollon pelouatensis Cossmann et Peyrot, 1924

Ranella tuberosa - Grateloup, 1833: 92, No. 420

Ranella tuberosa - Bellardi,1873: 235, pl. 15, fig. 7 Aquitanobursa tuberosa - Sanders et al. 2019: 259, fig. 7C (cum. syn.)

MATERIAl EXAMINED. Ranella tuberosa syntypes in Grateloup collection, University of Bordeaux, Talence, France.

Apollon pelouatensis lectotype MNHN.F.J06123; three paralectotypes MNHN.F.J06124, J06125, J06126 (Sanders et al., 2019). 


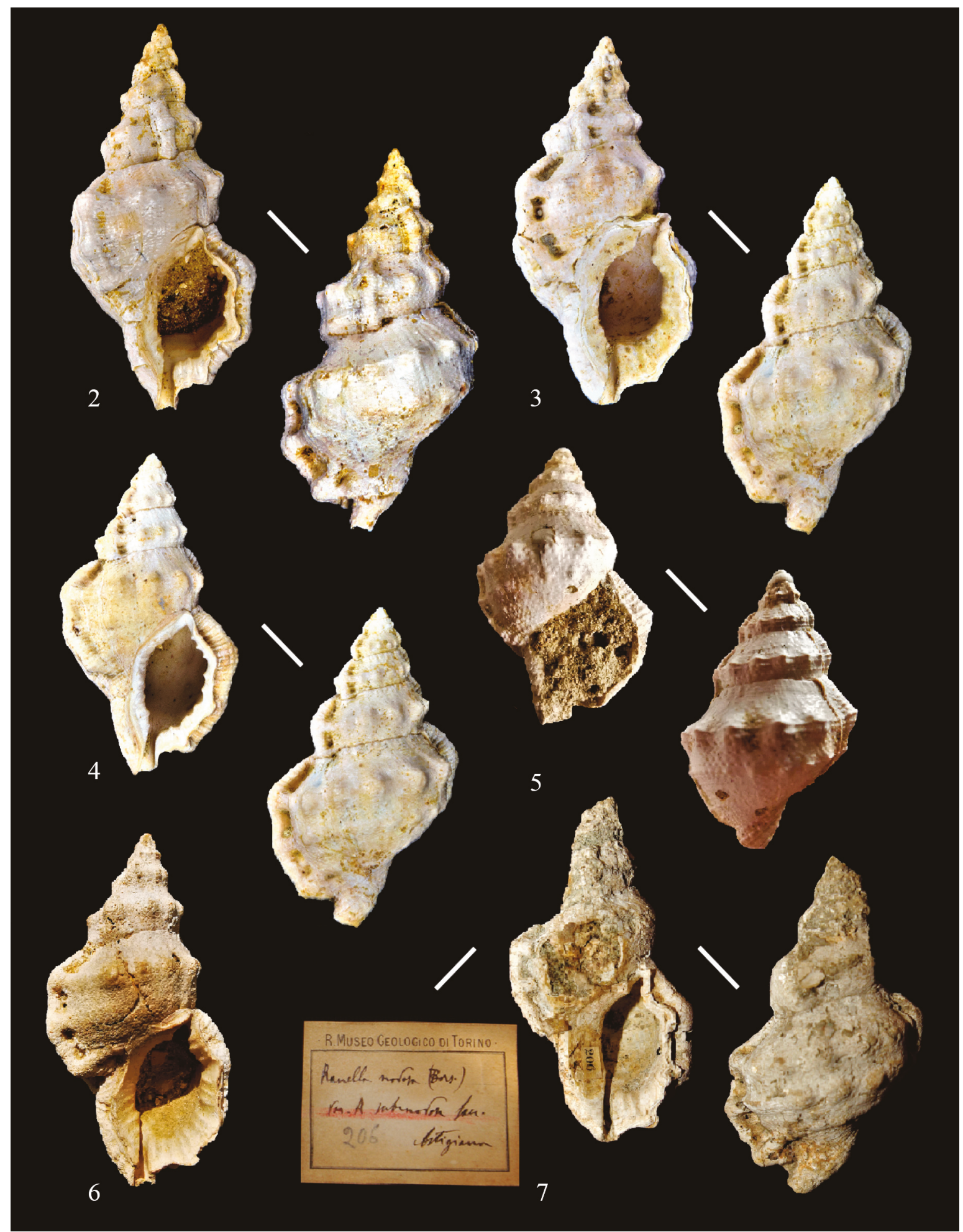

Figures 2-6. Bursa transeuntis n.sp. from Ciuciano, Tuscany, Italy, Pliocene, Piacenzian. Fig. 2: Holotype (H 47 x W 24); MRSNT-P/251; Fig. 3: paratype 1 (H 49 x W 25), temporarly retained in MFC. Fig. 4: paratype 2 (H 34 x W 18.2), temporarly retained in MFC. Fig. 5: paratype 3 (H 21 x W 12.8), juvenile stage; CS-PM. Fig. 6: paratype 4 (H 47.5 x W 24); CS-PM. Figure 7. Bursa nodosa (Borson, 1825) var. subanodosa Sacco, 1890, BS.010.03.002, MRSNT; (H 56 x W 29), syntype frontal and dorsal view and original label; Colli Astesi, Piedmont, Italy, Pliocene, Piacenzian. 


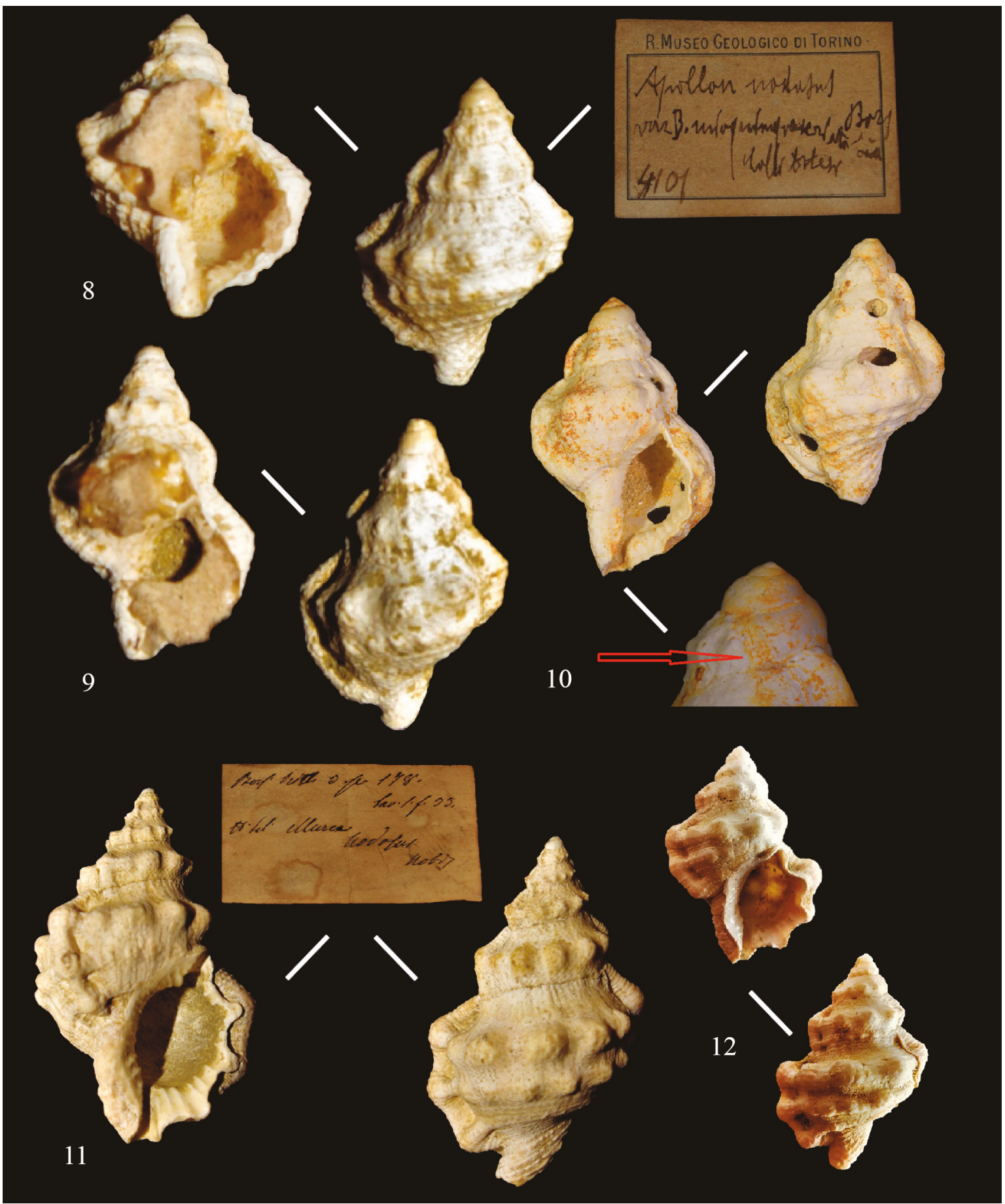

Figure 8. Bursa nodosa (Borson, 1825) var. mioquinqueseriata Sacco, 1890, from Colli Astesi, Piedmont, Italy, Pliocene, Piacenzian. BS.010.03.003, MRSNT; (H $1.3 \times$ W 0.9). Syntype, frontal, dorsal view and original label. Figure 9. BS.010.03.003, MRSNT; (H 1.4 x W 0.9). Syntype, frontal and dorsal view. Figure 10. Bursa nodosa (Borson, 1825), (H $11.4 \times$ W 8), juvenile stage: frontal, dorsal view and protoconch with the first teleoconch whorl (the arrow indicates the demarcation of the protoconch). Pozzavilla, Orciano Pisano, Tuscany, Italy, Pliocene, Piacenzian, MFC. Figure 11. Bursa nodosa (Borson, 1825), BS.010.03.001/01, Stefano Borson collection, CB.090.01, MRSNT; (H 38.3 x W 24.3), lectotype: frontal, dorsal view and original label; Valleandona, Colli Astesi, Piedmont, Italy, Pliocene, Piacenzian. Figure 12. Bursa nodosa (Borson, 1825), (H 21.5 x W 14.2). Juvenile stage, frontal and dorsal view; Sinalunga, Siena, Italy, Pliocene, Piacenzian, CS-PM. 


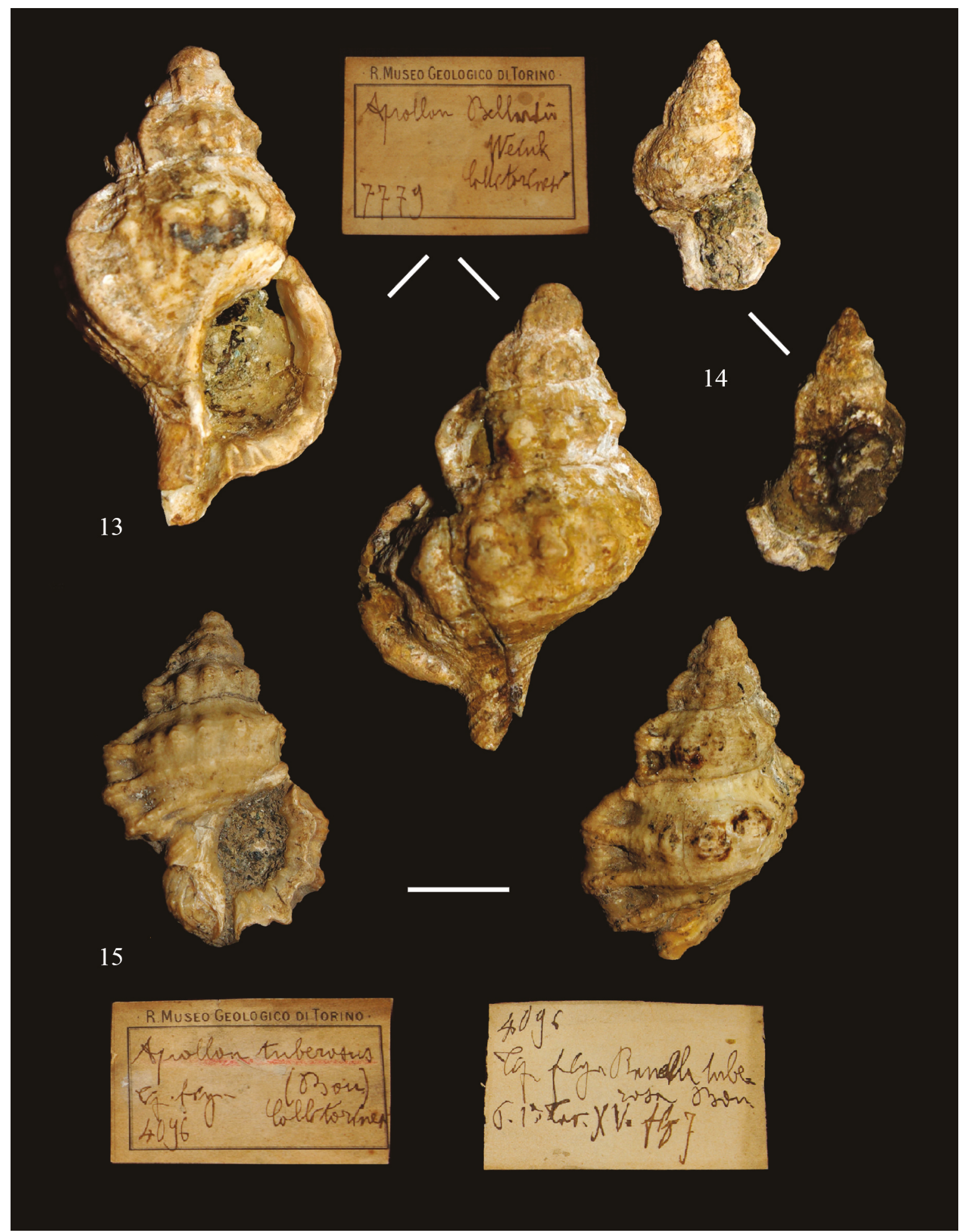

Figure 13. Ranella bellardii (Weinkauff, 1868) from Turin hills, Piedmont, Italy, Miocene/Elvezian (Serravallian). BS.010.03.004, MRSNT; (H 44 x W 27). Syntype: frontal, dorsal view and original label. Figure 14. BS.010.03.004, MRSNT; (H 23 x W 13). Syntype, frontal and dorsal view, specimen partially incomplete. Figures 15. Aquitanobursa tuberosa (Grateloup 1833), BS.010.03.005, Stefano Borson collection, MRSNT; (H 49 x W 33). Syntype: frontal, dorsal view and original labels; Turin hills, Piedmont, Italy, Miocene/Elvezian (Serravallian). 
Ranella tuberosa, one specimen ex Stefano Borson collection, Miocene/Elvezian (Serravallian), Turin hills, Piedmont, Italy, BS.010.03.005, MRSNT.

Ranella bellardii (Weinkauff, 1868), type by subsequent designation (Figs. 13, 14).

Bufonaria bellardii - Weinkauff, 1868: 75

Ranella bellardii - Bellardi, 1873: 235, pl. 15, fig. $6 \mathrm{a}-\mathrm{b}$

Ranella bellardii - Ferrero Mortara et al., 1982: 56

Material EXAmined. Ranella bellardii Miocene, Serravallian, Turin hills, Rio della Batteria, Baldissero, Piedmont, Italy, BS.010.03.004, MRSNT. One specimen plus one incomplete, ex Stefano Borson collection.

\section{CONCLUSIONS}

Bursa transeuntis $\mathrm{n}$. sp. has been compared with the morphologically closest species $B$. nodosa, with which has been confused in the past (Baluk, 1995, pag. 210, pl. 18, fig. 4), and with T. scrobilator scrobilator, with which was misidentified in the past and it was compared in recent times by Kovács \& Vicián (2017), but the two Authors though depict it on pag. 93 figs. 48-49, as Bursa ranelloides (Reeve, 1844 ) that, for a numbering inversion in the figures of the page 92 instead it refers to figs $46-47$ as Bursa scrobilator (Linnaeus, 1758) which is instead the real $B$. ranelloides, species whose morphological variability has been extensively treated by Landau et al. (2009).

For completeness, in addition to the type material of $B$. nodosa, the two forms listed by Sacco (1890), i. e. Ranella nodosa var. subanodosa Sacco, 1890 and Ranella nodosa var. mioquinqueseriata Sacco, 1890, have also been taken in to the consideration. According to Landau et al. (2004, pag. 66), these latter shells are considered simple varietal forms of $B$. nodosa and then placed in synonymy with it; the examination of the type material confirmed this classification. Further checking was done on Aquitanobursa tuberosa (Grateloup, 1833), species of Bursidae also provided with three spiral cords as $B$. nodosa, from which it differs for the larger average size and for the adorned sculpture displaying a greater number of smaller tubercles on the spiral cords. For generic attribution a check on the types of Ranella bellardii (Weinkauff, 1868), discussed subsequently by Bellardi (1873, pag. 31, tav. XV, figs. 5-6), was also carried out, which turned out to be a Ranella s.s. therefore not comparable with $B$. transeuntis $\mathrm{n}$. sp. The species depicted by the latter Author could refer to B. transeuntis n. sp. although it is not possible to confirm it with certainty because the images are referring to a rather juvenile shell but showing four distinct spiral cords not present in $B$. transeuntis $\mathrm{n}$. sp.

\section{ACKNOWLEDGMENTS}

We thank the Regional Museum of Natural Sciences of Turin (Turin, Italy), and in particular Annalaura Pistarino for technical support and the photographs of type material of Bellardi \& Sacco collection. We thank Massimo Appolloni, Civic Museum of Zoology of Rome (Rome, Italy) allowed the study of the collection Monterosato, Antonio Bonfitto, Museum of Zoology of Bologna (Bologna, Italy) for lending type material or provided information or photographs of such material under his care, Massimo Cresti (San Casciano, Firenze) for taking some photos, Stefano Dominici, Natural History Museum of Florence, for his help and advice in understanding the geo-stratigraphic part and Paolo Mariottini (Dipartimento di Scienze, Università "Roma Tre", Rome, Italy) for critical reading of the work and useful suggestions.

\section{REFERENCES}

Baluk W., 1995. Middle Miocene (Badenian) gastropods from Korytnica, Poland; Part II. Acta Geologica Polonica, 45: 153-256.

Bellardi L., 1873. I Molluschi dei Terreni Terziarii del Piemonte e della Liguria. Parte I. Cephalopoda, Pteropoda, Heteropoda, Gasteropoda (Muricidae et Tritonidae). Memorie della Reale Accademia delle Scienze di Torino, ser. 2, Tomo XXVII, 264 pp., 15 tavv.

Benvenuti M., Del Conte S., Scarselli N. \& Dominici S., 2014. Hinterland basin development and infilling through tectonic and eustatic processes: latest Messinian_gelasian Valdelsa Basin, Northern Apen- 
nines, Italy. Basin Research (2014) 26, 387-402, doi: 10.1111/bre. 12031

Borson S., 1825. Continuazione del Saggio di orittografia Piemontese. Memorie della Reale Accademia delle Scienze di Torino. serie 1, 29: 251-318.

Bozzetti L., 1991. Bursa nodosa (Borson, 1823) sopravvive in Australia? La Conchiglia, 260 (2): 2-4.

Brunetti M.M. \& Della Bella G., 2010. Tellina (Moerella) ciucianensis n. sp., un nuovo bivalve per il Pliocene toscano. Bollettino Malacologico, 46: 39-43.

Brunetti M.M. \& Vecchi G., 2005. Nuove specie di Gasteropodi del Piacenziano di rio Crevalese, Castell'Arquato (Piacenza, Italia). Bollettino Malacologico, 41: $1-22$.

Brunetti M.M. \& Forli M., 2010. Murexsul zezae n. sp. del Pliocene italiano (Gastropoda: Muricidae). Bollettino Malacologico, 46: 4-8.

Capezzuoli E., Foresi L. M., Salvatorini G. \& Sandrelli F., 2005. New data on the Middle Pliocene sedimentation in the souther Valdelsa basin (Siena, Italy). Bollettino della Società geologica Italiana, Volume Speciale, 4: 95-103.

Caprotti E., 1976. Malacofauna dello stratotipo Piacenziano (Pliocene di Castell'Arquato). Conchiglie, 12: $1-56$.

Chirli C., 1997. Malacofauna Pliocenica Toscana. Vol. I. Superfamiglia Conoidea. B.M.B. Firenze, 129 pp, 29 pls.

Chirli C., 2008. Malacofauna Pliocenica Toscana. Vol. 6: Neotaenioglossa. Chirli C. Ed., Grafiche PDB, Tavarnelle, 128 pp., 38 pls.

Coppi F., 1880. Del terreno Tabiano Modenese e de' suoi fossili. Regio Comitato Geologico d'Italia, 11:218228. Tipografia Barbera, Roma.

Cossmann M., 1903. Essais de Paléoconchologie comparée. Livraison 5. F. R. de Rudeval, Paris, 215 pp., 9 pls.

Cossmann M. \& Peyrot A., 1924. Conchologie néogénique de l'Aquitaine (Suite). Actes de la Société linnéenne de Bordeaux, 75: 193-318.

Crocetta F., Caputi L., Paz-Sedano S., Tanduo V., Vazzana A. \& Oliverio M., 2020. High genetic connectivity in a gastropod with long-lived planktonic larvae. Journal of Molluscan Studies, 36: 42-55. https://doi:10.1093/mollus/eyz032

D’Ancona C., 1872. Malacologia Pliocenica Italiana. 2: 55-143, 9. Tipografia Barbera, Firenze.

De Folin L. 1884. Une série de mollusques des explorations de 1881-1883. Les Fonds de la Mer, 4: 201212.

Dell'Angelo B. \& Forli M., 2000. A new species of Marginella (Mollusca, Gastropoda) from the Italian Pliocene. Bollettino Malacologico, 36: 93-98.

Dominici S., Danise S. \& Benvenuti M., 2018. Pliocene stratigraphic paleobiology in Tuscany and the fossil record of marine megafauna. Earth-Science Review, 176: 277-310.

Ferrero Mortara E., Montefameglio L., Tampieri R. \& Pavia G., 1982. Catalogo dei tipi e degli esemplari figurati della collezione Bellardi e Sacco, I. Cataloghi del Museo Regionale di Scienze Naturali di Torino, 6: 1-327.

Grateloup J. P. S. de, 1833. Tableau des coquilles fossiles qu'on rencontre dans les terrains calcaire tertiaires (faluns) des environs de Dax, département des Landes. Actes de la Société linnéenne de Bordeaux, 6: 159-164.

Greco A. \& Lima N., 1974. Repertorio dei molluschi marini Plio-Pleistocenici della Sicilia. Parte I, Lavori dell'Istituto di Geologia della Università di Palermo, 14: 1-140.

Kovács Z. \& Vicián Z., 2018. Middle Miocene Tonnoidea and Ficoidea Caenogastropoda) assemblages from Letkés (Hungary). Fragmenta Palaeontologica Hungarica, (2017) 34: 75-104.

Inzani A. 1986, La famiglia Bursidae nel Pliocene italiano. Hobby Fauna International News, 2: 56-57.

Landau B., Beu A. \& Marquet R., 2004. The early Pliocene Gastropoda (Mollusca) of Estepona, Southern Spain. Part 5: Tonnoidea, Ficoidea. Palaeontos, 5: 35-102, 10 pls.

Landau B., Harzhauser M. \& Beu A.G., 2009. A Revision of the Tonnoidea (Caenogastropoda, Gastropoda) from the Miocene Paratethys and their Palaeobiogeographic Implications. Jahrbuch der Geologischen Bundesanstalt, 149: 61-109.

Linnæus C., 1758. Systema naturæ per regna tria naturæ, secundum classes, ordines, genera, species, cum characteribus, differentiis, synonymis, locis. Tomus I. Editio decima, reformata. Salvius, Holmiæ, 824 pp.

Malagoli M., 1884. Tortoniano di Monte Baranzone. Bollettino Società dei Naturalisti di Modena, Rendiconti delle Adunanze, serie 3, 2: 81-86.

Nalin R., Ghinassi M., Foresi L. M. \& Dallanave E., 2016. Carbonate deposition in restricted basins: a Pliocene case study from the central Mediterranean (Northwestern Apennines). Journal of Sedimentary Research, 86 (3): 236-267. https://doi.org/10.2110/jsr.2016.14

Pavia G., 1976. I Molluschi del Pliocene inferiore di Monteu Roero (Alba, Italia NW). Bollettino della Società Paleontologica Italiana, 14: 99-175.

Reeve L. A., 1844. Monograph of the genus Ranella. In: Conchologia Iconica, or, illustrations of the shells of molluscous animals, vol. 2, pl. 1-8 and unpaginated text. L. Reeve \& Co., London.

Sacco F., 1890. Catalogo Paleontologico Terziario del Piemonte. Bollettino della Società Geologica Italiana, 8: 281-292.

Sanders M. T., Merle D. \& Puillandre N., 2019. A review 
of fossil Bursidae and their use for phylogeny calibration. Geodiversitas, 41: 247-265.

https://doi.org/10.5252/geodiversitas2019v41a5

Sanders M. T., Merle D., Laurin M., Bonillo C. \& Puillandre N., 2020. Raising names from the dead: a time-calibrated phylogeny of frog shells (Bursidae, Tonnoidea, Gastropoda) using mitogenomic data. Molecular Phylogenetics and Evolution, 156.

https://doi.org/10.1016/j.ympev.2020.107040

Smriglio C., Furfaro G., Trillò P., Appolloni M. \& Paolo Mariottini P., 2019. A review of the Atlantic-Mediter- ranean Bursa scrobilator (Linnaeus, 1758) species complex. Molluscan Research, 39: 341-354. https://doi.org/10.1080/13235818.2019.1600397

Vera Peláez J.L., Lozano-Francisco M. del C., MuñizSolís R., Gili C., Martinell J., Domènech R., Palmqvist P. \& Guerra-Merchán A., 1995. Estudio preliminar de la malacofauna del Plioceno de Estepona (Málaga, España). Iberus, 13: 93-117.

Weinkauff H.C., 1868. Die Conchylien des Mittelmeeres, ihre geographische und geologische Verbreitung. Band II. Mollusca cephala. Theodore Fischer, Cassel, 512 pp. 